\title{
Genetic Analysis of an Artificial Insemination Progeny Test Program
}

\author{
O. González-Recio, ${ }^{1}$ C. Ugarte ${ }^{2}$ and R. Alenda ${ }^{1}$ \\ ${ }^{1}$ Departamento de Producción Animal E.T.S.I. Agrónomos-Universidad Politécnica \\ Ciudad Universitaria s/n 28040 Madrid, Spain \\ ${ }^{2}$ ABEREKIN S.A. Parque Tecnológico, Edificio 600, 48160 Derio (Bizkaia), Spain
}

\begin{abstract}
The success of the progeny test (PT) program from one Spanish artificial insemination (AI) organization was evaluated. The annual genetic trend for the organization was compared with PT programs from other countries. The relationships among parents' estimated breeding values (EBV) and PT results for sons were also studied. Estimated breeding values for type and production traits were obtained from international genetic evaluations from February 2004. The annual genetic gain of the Spanish PT program was similar to that of other international programs. The Spanish AI organization graduated $13 \%$ of its sampled bulls, and $52 \%$ of primiparous cows were daughters of Spanish bulls (32\% from proven bulls and $20 \%$ from sampling bulls).

Correlations between EBV for PT bulls and their pedigree indices $(0.52$ to 0.70$)$ were slightly lower than correlations between EBV for PT bulls and their parent averages (0.63 to 0.73$)$. Both young and mature cows contributed to genetic progress. Success of PT bulls (defined by number of second-crop daughters) depended mainly on their EBV for final score, protein yield, and the type-production index. Significant correlations of sire EBV were found for final score and type-production index with the number of second-crop daughters $(0.22$ and 0.17). Likewise, significant correlations of dam EBV for final score and type-production index with the number of second crop daughters were found $(0.25$ and 0.18 ). Final score and protein yield were the main factors in success of a PT bull. The type-production index for PT bulls was not important for success unless it was 2.5 standard deviations above average. The PT bulls with low EBV for type-production index were used as proven bulls when they had higher EBV either for protein or final score.
\end{abstract}

(Key words: progeny test, second-crop daughter)

Received July 5, 2004.

Accepted October 15, 2004.

Corresponding author: Oscar González-Recio; e-mail: ogrecio@ pan.etsia.upm.es.
Abbreviation key: $\mathbf{E B V}^{\mathbf{a}}$ = estimated breeding value adjusted by annual genetic progress, FS = final score, $\mathbf{F L}=$ overall feet and legs index, ICO $=$ Spanish typeproduction selection index, MGS = maternal grandsire, MGGS = maternal great-grandsire, PA = parent average, $\mathbf{P I}=$ pedigree index, $\mathbf{P T}=$ progeny test(ing), $\mathbf{S C D}=$ second-crop daughters, UDC = udder composite.

\section{INTRODUCTION}

Genetic improvement in dairy cattle depends mainly on successful AI organizations. Several authors (Meinert et al., 1992; Willam et al., 2002; Norman et al., 2003) reported that the success of progeny test (PT) programs depends on number of sampled bulls, selection intensity, progeny group size, and selection of dams.

Many countries have improved their dairy populations by introducing North American Holstein genes. Competitive AI organizations have played an important role in changing local populations, and their PT programs have been improved in recent decades. Now, a competitive global semen market exists (Dekkers et al., 1996). Hence, AI organizations should obtain successful PT bulls that ensure the marketing of their semen and provide genetic progress to the dairy population. Moreover, AI organizations should consider semen market characteristics in the selection of parents. Sires are known worldwide, therefore the success of a PT program lies in the proper identification of the most suitable sires and dams from around the world. Dams are expected to be genetically better than sires because the female dairy population is much larger than the male population. However, the accuracy of cow EBV are often low at the time they are selected as bull dams.

According to Powell et al. (2003), every country should analyze its PT program because the success of PT programs from different countries can not be compared, even though breeding goals are very similar and selection indices have correlations near 0.90. The first Spanish PT program was established in 1986. This program was based on reducing the generation interval, rigorous selection of parents of young bulls, and a high selection differential in the dam-sire path via MOET (multiple ovulation and embryo transfer) from the worldwide female population. These concepts were 
studied using a cow nucleus herd by Nicholas and Smith (1983) and using a PT program in Italy (Burnside et al., 1992). The aim of the current study was to calculate Spanish annual genetic gain and compare it with genetic gain in other PT programs. Furthermore, we wanted to determine relationships among the success of PT bulls and their parents' EBV for type and production traits from Spain.

\section{MATERIALS AND METHODS}

\section{Data}

The Spanish EBV of bulls, their sires, maternal grandsires (MGS), and their maternal great-grandsires (MGGS) were obtained from 67,409 proven bulls from the February 2004 International Bull Evaluation Service (Interbull, 2004a) evaluations. The EBV of the bulls' Spanish dams were provided by the Spanish National Holstein Association (CONAFE). The EBV of the bulls' foreign dams (from Canada, Italy, the Netherlands, and United States) were provided by their respective Holstein Associations. Those EBV were converted to the Spanish base using the conversion equations provided by February 2004 Interbull genetic evaluations. Progenitors without EBV were considered missing values.

\section{Definitions}

Second-crop daughters. The AI organizations begin collecting semen when test bulls are 14 mo old, and after 3 mo, dairy producers have semen from those young bulls available. Average age at first calving in Basque and Navarran dairy populations is $28 \mathrm{mo}$. Bulls in a PT program have their first EBV that includes daughter information when they are about 63 mo old. Daughters born to this point were considered first-crop daughters. Daughters born in the Basque and Navarra Autonomous Regions when bulls were between 72 and 96 mo of age were considered second-crop daughters (SCD). Bulls born after 1997 did not have the chance to have SCD in this study.

Traits and indices considered. Production traits that were analyzed included milk, fat, and protein yields $(\mathrm{kg})$. The indices considered were the Spanish type-production index (ICO), overall feet and legs index (FL), udder composite (UDC), and final score (FS). Latter indices (FL, UDC, and FS) are included in the ICO [1] index (Interbull, 2004b).

$$
\begin{gathered}
\text { ICO }=12 \% \text { Milk }+12 \% \text { Fat }+32 \% \text { Protein } \\
+3 \% \text { Protein }(\%)+10 \% \text { FL }+16 \% \text { UDC } \\
+9 \% \text { FS }+3 \% \text { Somatic Cell Score } \\
+3 \% \text { Functional Herd Life }
\end{gathered}
$$

\section{Genetic Trend}

Average annual genetic gain was estimated for traits and indices using the REG procedure (SAS Institute, 1998) and the following model:

$$
E B V_{i}=a_{i}+b_{i} \cdot Y B+\varepsilon
$$

where $\mathrm{EBV}_{\mathrm{i}}$ is the bulls' estimated breeding value for trait or index $i, \mathrm{a}_{\mathrm{i}}$ is the intercept for trait or index $i$, $\mathrm{b}_{\mathrm{i}}$ is estimated annual genetic gain for trait or index $i$, and YB is year of birth of the proven bulls. The 67,409 bulls with international genetic evaluations were included.

Differences among countries for annual genetic gain in ICO were estimated using the GLM procedure (SAS Institute, 1998) and the following model:

$$
I C O=C+Y B+Y B \times C+\varepsilon
$$

where $\mathrm{C}$ is country (to adjust for different intercepts), YB is year of birth of the proven bulls, and YB $\times \mathrm{C}$ is year of birth-country interaction to calculate genetic gain of each country. Two periods were considered, bulls born since 1986 and bulls born since 1994. Orthogonal contrasts were used to estimate differences between the Spanish genetic trends and trends of other testing programs. Countries without influence in the Spanish PT programs were grouped together as "other countries".

\section{Pedigree Index and Parent Average}

Pedigree index (PI) and parent average (PA) were defined as:

$$
\begin{gathered}
P I_{i}=\frac{1}{2} E B V_{S}+\frac{1}{4} E B V_{M G S}+\frac{1}{8} E B V_{M G G S} \\
P A_{i}=\frac{1}{2} E B V_{S}+\frac{1}{2} E B V_{D}
\end{gathered}
$$

where $\mathrm{EBV}_{\mathrm{S}}, \mathrm{EBV}_{\mathrm{D}}, \mathrm{EBV}_{\mathrm{MGS}}$, and $\mathrm{EBV}_{\mathrm{MGGS}}$ are estimated breeding values of sire, dam, MGS, and MGGS, respectively, for trait or index $i$.

Pearson correlations (SAS Institute, 1998) were estimated among EBV for proven bulls and PI, PA, EBV of dam, sire, MGS, and MGGS.

\section{Adjusted EBV}

To compare EBV with the success of noncontempo[1] rary (born in different years) animals, the EBV for bulls, their sires, and their dams were adjusted for annual genetic gain as described below: 
Table 1. Means, SD, and average annual genetic gain $(\Delta \mathrm{G})$ of bulls with international genetic evaluations for milk, fat, and protein, overall feet and legs index (FL), udder composite (UDC), final score (FS), and Spanish selection index (ICO). ${ }^{1}$

\begin{tabular}{llclrrrr}
\hline & Milk & \multicolumn{1}{l}{ Fat } & Protein & \multicolumn{1}{l}{ FL } & UDC & \multicolumn{1}{l}{ FS } & \multicolumn{1}{l}{ ICO } \\
\hline $\mathrm{N}$ & 67,409 & 67,409 & 67,409 & 67,409 & 67,409 & 67,409 & 67,409 \\
Mean & 335 & 11.0 & 11.8 & 0.20 & 0.29 & 0.34 & 617 \\
$\mathrm{SD}$ & 535 & 17.9 & 16.8 & 0.20 & 0.98 & 0.81 & 552 \\
$\Delta \mathrm{G}$ & 76.67 & 2.17 & 2.84 & 0.05 & 0.07 & 0.08 & 96.11 \\
\hline
\end{tabular}

${ }^{1} \mathrm{~N}$ is number of records. International genetic evaluations from February 2004 were used.

$$
E B V_{i}^{a}=E B V_{i}+t \cdot \Delta G_{i}
$$

where $\mathrm{EBV}_{\mathrm{i}}^{\mathrm{a}}$ is adjusted estimated breeding value $\left(\mathbf{E B V}^{\mathbf{a}}\right)$ for trait or index $i, \mathrm{EBV}_{\mathrm{i}}$ is estimated breeding value for trait or index $i$ on the February 2004 genetic evaluation, $\Delta \mathrm{G}_{\mathrm{i}}$ is overall international annual genetic gain (previously calculated from Interbull sire population) for trait or index $i$, and $\mathrm{t}$ is years from the year of birth of the animal up to year 1997 (bulls born after this year were not considered because they did not have SCD).

\section{Dams}

Proven bulls were categorized, grouped, and analyzed according to the age of their dams when they were conceived. Two groups were defined based on age of dam: heifers and mature cows. Dams were considered heifers when they conceived before the age of $25 \mathrm{mo}$. Such dams were considered primiparous at the birth of the PT bull. Dams that were 25 mo or older at conception were considered mature cows. Differences in proven bulls' $\mathrm{EBV}^{\mathrm{a}}$ were estimated based on their group. The proven bulls' EBV ${ }^{\mathrm{a}}$ were used to compare noncontemporary (born in different years) animals. The GLM procedure (SAS Institute, 1998) was used to estimate differences in young and mature cows' sons' EBV ${ }^{\mathrm{a}}$. In addition, average dam and sire EBV were compared by PT year.

\section{Probability of Success of PT Bulls}

The success of the PT bulls was measured through the number of SCD. Only graduated bulls had SCD, and more SCD means greater impact of the bull. Pearson correlations were estimated between the number of SCD for a bull and his EBV ${ }^{\text {a }}$, between the number of SCD for a bull and his sire's EBV ${ }^{\mathrm{a}}$, and between the number of SCD for a bull and his dam's EBV ${ }^{\mathrm{a}}$. Bulls with less than 100 SCD were considered unsuccessful. Probability of success of PT bulls was estimated according to their $\mathrm{EBV}^{\mathrm{a}}$ (in genetic standard deviation units from the average population).

\section{RESULTS AND DISCUSSION}

\section{Genetic Trend}

Table 1 shows international means, standard deviations, and average annual genetic gain for the traits and indices that were used to adjust EBV for comparison with noncontemporary animals. Differences for genetic gain, since 1986 and since 1994, for various countries are shown in Table 2. Since 1986, United Kingdom bulls had the highest annual genetic gain for ICO (sampling 80 to 130 young bulls per year since 1990), but the UK had the lowest intercept $(-243)$. The United States had the lowest genetic gain because they had the highest intercept $(+130)$. The United States sampled more than 1000 bulls annually and spread its Holstein genetics around the world in the last decades in the global semen market. This led to a higher annual genetic gain for countries with the lowest intercepts. Annual genetic gain in the Spanish PT program (110.7) was not statistically different from the genetic gain of the Canadian (109.5) or Italian (113.2) PT programs. Remaining PT programs had lower annual genetic gain.

Since 1994, the annual genetic gain has been similar for every country except for the United States, which had the lowest genetic gain because it had the highest genetic base (intercept $=+870$ ). The UK program reached the intercept of the rest of the European programs in 1994. The "other countries" group had the highest annual genetic gain, probably because in 1994 they had the lowest intercept and they imported North American genes in last decade, improving their populations substantially. Due to correlations between evaluations from Spain and other countries being assumed to be less than one, this group of "other countries" was affected the most because few daughters from those bulls were born in Spain. The Spanish PT program had one of the lowest intercepts (-121) in 1986, whereas in 1994 it was +733 . The 1994 intercept is similar to those for the Netherlands (+736) and Italy (+760). Since 1994, no country had a statistically higher annual genetic gain. The Spanish PT program could be considered successful. 
Table 2. Annual genetic gain ( $\Delta \mathrm{G})$ and its standard error (SE), by country using bulls born between 1986 and 1999 with international genetic evaluations for Spanish selection index (ICO). ${ }^{1}$

\begin{tabular}{|c|c|c|c|c|c|c|c|c|}
\hline \multirow[b]{2}{*}{ Country } & \multicolumn{4}{|c|}{ From 1986 to 1999} & \multicolumn{4}{|c|}{ From 1994 to 1999} \\
\hline & $\mathrm{N}$ & Intercept & $\Delta \mathrm{G}_{\mathrm{ICO}}$ & SE & $\mathrm{N}$ & Intercept & $\Delta \mathrm{G}_{\mathrm{ICO}}$ & $\mathrm{SE}$ \\
\hline Canada & 4699 & 34 & $109.5^{\mathrm{NS}}$ & 1.4 & 1853 & 828 & $109.7^{\mathrm{NS}}$ & 5.2 \\
\hline Germany & 9701 & -118 & $108.8^{*}$ & 1.2 & 4907 & 604 & $119.3^{\mathrm{NS}}$ & 4.2 \\
\hline Spain & 559 & -121 & 110.7 & 4.3 & 310 & 733 & 124.1 & 14.6 \\
\hline France & 7583 & 81 & $95.7^{* *}$ & 1.1 & 3147 & 825 & $106.2^{\mathrm{NS}}$ & 4.9 \\
\hline United Kingdom & 1325 & -243 & $134.5^{* *}$ & 2.8 & 569 & 810 & $115.5^{\mathrm{NS}}$ & 10.9 \\
\hline Italy & 3683 & 87 & $113.2^{\mathrm{NS}}$ & 1.7 & 1823 & 760 & $124.2^{\mathrm{NS}}$ & 5.6 \\
\hline Netherlands & 6722 & -57 & $96.8^{* *}$ & 1.3 & 3473 & 736 & $114.2^{\mathrm{NS}}$ & 4.5 \\
\hline United States & 18,693 & 130 & $94.5^{* *}$ & 0.7 & 7541 & 870 & $92.0^{*}$ & 2.6 \\
\hline Others & 14,059 & -155 & $95.5^{* *}$ & 1.1 & 6880 & 422 & $145.8^{\mathrm{NS}}$ & 4.0 \\
\hline
\end{tabular}

\footnotetext{
${ }^{\mathrm{NS}}$ Not significantly different in annual genetic gain from Spanish program.

*Significantly different annual genetic gain from Spanish program $(P<0.05)$.

**Significantly different annual genetic gain from Spanish program $(P<0.01)$.

${ }^{1}$ International genetic evaluations from February 2004 were used. $\mathrm{N}=$ Number of bulls with genetic evaluations per country.
}

\section{Spanish PT Program}

The Spanish PT program that was studied was chosen because it is the oldest Spanish program and the program with the most data available. The AI organization and its PT program tested 20 young bulls in 1991. Those bulls were born in 1990 and were genetically better (intercept $=498$ units of ICO) than the Spanish average (intercept $=428$ units of ICO). The average Spanish bulls had a lower intercept and therefore higher annual genetic gain (110.7 units of ICO) than the PT program studied (98.0). In 1994, this AI organization had an intercept of 820 units of ICO (Spanish average intercept $=733$ ) and since that year its annual genetic gain was 102.2 $( \pm 24.3)$ units of ICO. Since 1998, 32 young bulls have been sampled per year by this PT program. Also, the number of cows in the Spanish milking record system rose from 50,000 in 1987 to more than 370,000 in 2001. This record system has improved in quantity and quality in the last decade, and all cows in the milk-recording scheme were classified for type traits. First-crop progeny group sizes in Spanish PT programs are now between 80 to 120 daughters. Spain's $4 \mathrm{AI}$ organizations now sample more than 130 young bulls per year.

Most sires of the PT bulls came from North America (139 sires from the United States and 30 from Canada). Other countries of origin for sires of the PT bulls were the Netherlands (10 sires), Spain (4 sires), France (2 sires), Italy (1 sire), and Germany (1 sire).

The dams of the PT bulls were mainly from the United States (187 dams), Spain (63 dams), Canada (30 dams), the Netherlands (16 dams), and Italy (10 dams). Most PT bulls with foreign dams were introduced into the program as embryos.

Trends of pedigree index and parent average. Average PI and PA of PT bulls increased every year since 1991 (Table 3). Annual increase in ICO was 97.2 and 85.4 for PA and PI, respectively. The parent selec-

Table 3. Means for pedigree index and parent average for production traits (milk, fat, and protein), overall feet and legs index (FL), udder composite (UDC), final score (FS), and Spanish selection index (ICO) by year of progeny test from 1991 to $2001 .^{1}$

\begin{tabular}{|c|c|c|c|c|c|c|c|c|c|c|c|c|c|c|c|c|}
\hline Year & \multicolumn{8}{|c|}{ Pedigree index } & \multicolumn{8}{|c|}{ Parent average } \\
\hline 1991 & 5 & 564 & 257 & 6 & 7 & 0.34 & 0.62 & 0.64 & 18 & 647 & 247 & 8 & 6 & 0.57 & 0.75 & 0.84 \\
\hline 1993 & 6 & 750 & 396 & 11 & 14 & 0.57 & 0.55 & 0.67 & 17 & 813 & 391 & 11 & 13 & 0.67 & 0.65 & 0.86 \\
\hline 1994 & 6 & 731 & 509 & 12 & 17 & 0.04 & 0.44 & 0.64 & 19 & 977 & 641 & 17 & 21 & 0.30 & 0.55 & 0.95 \\
\hline 1995 & 12 & 757 & 532 & 14 & 17 & 0.16 & 0.46 & 0.50 & 19 & 1014 & 606 & 21 & 21 & 0.23 & 0.81 & 0.91 \\
\hline 1996 & 16 & 824 & 634 & 16 & 20 & 0.21 & 0.44 & 0.59 & 22 & 1089 & 752 & 24 & 26 & 0.44 & 0.54 & 0.82 \\
\hline 1999 & 27 & 1163 & 842 & 20 & 27 & 0.49 & 1.05 & 1.00 & 30 & 1497 & 959 & 26 & 32 & 0.64 & 1.55 & 1.49 \\
\hline 2000 & 29 & 1161 & 901 & 23 & 26 & 0.62 & 0.81 & 1.09 & 30 & 1480 & 1050 & 30 & 33 & 0.08 & 1.17 & 1.42 \\
\hline 2001 & 29 & 1255 & 813 & 20 & 26 & 1.08 & 1.15 & 1.34 & 30 & 1681 & 1034 & 29 & 34 & 1.33 & 1.68 & 1.89 \\
\hline
\end{tabular}

${ }^{1} \mathrm{~N}=$ Number of records; number of records of PI and PA within a year may not agree due to missing EBV of grandsires or great-grandsires. 
Table 4. Pearson correlations between EBV of proven bulls and their parent average (PA), pedigree index (PI), EBV of their sire, EBV of their dam, EBV of their maternal grand sire (MGS), and EBV of their maternal great-grandsire (MGGS).

\begin{tabular}{lcccccc}
\hline Progeny test bulls' EBV & PA & PI & Sire & Dam & MGS & MGGS \\
\hline $\mathrm{N}$ & 174 & 113 & 204 & 199 & 184 & 124 \\
Milk & $0.69^{* *}$ & $0.60^{* *}$ & $0.56^{* *}$ & $0.51^{* *}$ & $0.38^{* *}$ & $0.33^{* *}$ \\
Fat & $0.63^{* *}$ & $0.61^{* *}$ & $0.52^{* *}$ & $0.42^{* *}$ & $0.21^{* *}$ & $0.22^{* *}$ \\
Protein & $0.73^{* *}$ & $0.65^{* *}$ & $0.60^{* *}$ & $0.58^{* *}$ & $0.53^{* *}$ & $0.48^{* *}$ \\
Overall feet and legs index & $0.68^{* *}$ & $0.70^{* *}$ & $0.56^{* *}$ & $0.39^{* *}$ & $0.22^{* *}$ & $0.00^{\mathrm{NS}}$ \\
Udder composite & $0.66^{* *}$ & $0.52^{* *}$ & $0.55^{* *}$ & $0.43^{* *}$ & $0.21^{* *}$ & $0.14^{\mathrm{NS}}$ \\
Final Score & $0.69^{* *}$ & $0.63^{* *}$ & $0.57^{* *}$ & $0.44^{* *}$ & $0.34^{* *}$ & $0.31^{* *}$ \\
Spanish selection index & $0.69^{* *}$ & $0.66^{* *}$ & $0.59^{* *}$ & $0.54^{* *}$ & $0.42^{* *}$ & $0.48^{* *}$ \\
\hline
\end{tabular}

$* P<0.05$.

$* * P<0.01$.

tion was consistent with overall international genetic progress for every trait and index. Pearson correlations among PI, PA, EBV of sire, EBV of dam, EBV of MGS, EBV of MGGS, and bull EBV are shown in Table 4. Due to Mendelian segregation, PI and PA do not often agree with EBV. Correlations between bull EBV and PA ranged from 0.63 to 0.73 and they were slightly higher than correlations between bull EBV and PI for every trait and index considered (0.52 to 0.70 ). Because dam EBV used in this study came from February 2004 genetic evaluations, they are influenced by their sons' EBV and differ from their EBV at the time of selection as bull dam. The sire EBV showed higher correlation (0.52 to 0.60 ) than those of dams (0.39 to 0.58 ), probably because sires' proofs are more accurate than dams'. Preferential treatment of bull dams may have contributed to this result as well. Preferential treatment has been studied widely in other papers (Mao et al., 1991; Weigel et al., 1994) and it was avoided (insofar as possible) in this PT program. The PT bull EBV for protein, FS, and ICO showed similar correlations with MGS and MGGS EBV, and showed slightly lower correlations with dam EBV. Butcher and Legates (1975) found lower correlations for milk yield. Mao et al. (1991) found higher correlations between PTA of the bull and PTA of its dam, probably because they did not use the conversion equations. Correlations between bull EBV for protein, FS, and ICO and their dam EBV were not significantly better than with MGS and MGGS. Recommending the use of PA or PI at selection of young bulls is not straightforward due to uncertainty regarding cows' proof at the time of selection as a bull's dam. Hence, as the correlation between EBV and PA was higher than with PI, the young bulls should be selected based on PA, but they should have an appropriate PI to consider dam pedigree.

Dams. Approximately 33\% of the PT bulls were from first-parity dams. The mean $\mathrm{EBV}^{\mathrm{a}}$ for sons from primiparous cows and mature cows were not statistically different. First-parity and mature cows transmitted the same genetic gain to their sons. However, conformation indices of sons from mature cows appeared higher. On the contrary, production traits were higher for sons of primiparous cows. Selecting heifers as bull dams implies a certain risk because the standard deviations of their sons' EBV were higher than the standard deviations of EBV for bulls from mature cows (Table 5). However, that risk was offset somewhat because a lower generation interval and a high selection intensity on PI and PA were applied to sons of primiparous cows. Nonsignificant differences were found for the country of origin of dams (results not shown).

Table 6 shows average sire and dam EBV per PT year. Average EBV of selected dams was not much higher than average EBV of sires. This result is consistent with the difficulty of selecting the best dams because EBV of dams can change more drastically through time. The AI organizations usually seek out cows whose EBV are higher than the sire EBV at time of young bull sampling. However, dam EBV had lower accuracy and repeatability.

Probability of success of PT bulls. Only $13 \%$ of PT bulls had more than 100 SCD. A selection intensity of 2.201 was applied after sampling bulls. Powell et al. (2003) reported a lower percentage of success for PT programs in Australia, Canada, Denmark, Italy, Swe-

Table 5. Average adjusted $\mathrm{EBV}^{1}$ (and SD) for sons of primiparous cows and mature cows.

\begin{tabular}{lcc}
\hline & $\begin{array}{c}\text { Primiparous } \\
\text { cows' sons }\end{array}$ & $\begin{array}{l}\text { Mature } \\
\text { cows' sons }\end{array}$ \\
\hline $\mathrm{N}$ & 68 & 142 \\
Spanish selection index & $+1102(404)$ & $+1114(371)$ \\
Milk & $+745(464)$ & $+734(346)$ \\
Fat & $+20(20)$ & $+21(16)$ \\
Protein & $+26(12)$ & $+25(11)$ \\
Overall feet and legs index & $+0.24(1.0)$ & $+0.40(1.0)$ \\
Udder composite & $+0.84(1.0)$ & $+0.89(0.9)$ \\
Final score & $+0.84(0.8)$ & $+0.93(0.8)$ \\
\hline
\end{tabular}

${ }^{1} \mathrm{EBV}$ adjusted by annual genetic gain in order to compare noncontemporary animals. $\mathrm{N}=$ Number of records. 
Table 6. Sires' and dams' average EBV (Interbull, February 2004) for milk, fat, protein, overall feet and legs index (FL), udder composite (UDC), final score (FS), and Spanish selection index (ICO) by year. ${ }^{1} \mathrm{~N}$ is number of records (some sires or dams may be repeated).

\begin{tabular}{|c|c|c|c|c|c|c|c|c|c|c|c|c|c|c|c|c|}
\hline \multirow{2}{*}{$\begin{array}{l}\text { Progeny } \\
\text { test year }\end{array}$} & \multicolumn{8}{|c|}{ Sires } & \multicolumn{8}{|c|}{ Dams } \\
\hline & $\mathrm{N}$ & ICO & Milk & Fat & Protein & FL & UDC & FS & $\mathrm{N}$ & $\mathrm{ICO}$ & Milk & Fat & Protein & FL & UDC & FS \\
\hline 1991 & 18 & 837 & 434 & 8 & 11 & 0.65 & 1.11 & 1.00 & 20 & 425 & 35 & 9 & -1 & 0.35 & 0.39 & 0.65 \\
\hline 1992 & 17 & 984 & 522 & 13 & 16 & 0.79 & 1.09 & 1.16 & 15 & 608 & 279 & 13 & 6 & 0.22 & 0.51 & 0.80 \\
\hline 1993 & 19 & 1026 & 526 & 13 & 21 & 1.34 & 0.68 & 0.72 & 17 & 621 & 295 & 8 & 6 & 0.17 & 0.56 & 0.99 \\
\hline 1994 & 20 & 955 & 259 & 12 & 24 & 0.19 & 0.64 & 0.86 & 21 & 926 & 546 & 21 & 19 & 0.19 & 0.59 & 0.88 \\
\hline 1995 & 22 & 928 & 686 & 17 & 22 & 0.17 & 0.47 & 0.59 & 19 & 1090 & 570 & 26 & 21 & 0.34 & 0.90 & 1.07 \\
\hline 1996 & 22 & 980 & 811 & 21 & 25 & 0.24 & 0.38 & 0.58 & 23 & 1181 & 732 & 21 & 25 & 0.52 & 0.87 & 1.07 \\
\hline 1997 & 23 & 1321 & 1095 & 22 & 29 & 0.70 & 1.02 & 1.29 & 24 & 1110 & 663 & 22 & 22 & 0.39 & 0.98 & 1.10 \\
\hline 1998 & 31 & 1369 & 1098 & 28 & 33 & 0.64 & 0.81 & 0.96 & 28 & 1031 & 578 & 24 & 21 & 0.35 & 1.00 & 1.18 \\
\hline 1999 & 30 & 1600 & 1120 & 29 & 35 & 0.51 & 1.80 & 1.51 & 31 & 1346 & 836 & 23 & 29 & 0.83 & 1.00 & 1.36 \\
\hline 2000 & 30 & 1455 & 1155 & 33 & 33 & 0.81 & 1.01 & 1.36 & 31 & 1549 & 975 & 31 & 34 & 0.87 & 1.31 & 1.53 \\
\hline 2001 & 30 & 1740 & 1083 & 26 & 35 & 1.80 & 1.82 & 1.95 & 32 & 1624 & 1004 & 31 & 34 & 0.92 & 1.49 & 1.79 \\
\hline
\end{tabular}

${ }^{1} \mathrm{~N}=$ Number of records (some sires or dams may be repeated). Number of records of sires and dams within a year may not agree because of missing EBV.

den, the Netherlands, United States, and France, and higher success in Germany. Successful PT bulls had an average of $608( \pm 480)$ registered daughters in second crop born within 24 mo of the initial EBV that contained daughter information. Annually, at least 32 and $20 \%$ of registered Holstein primiparous cows are daughters of Spanish proven and sampling bulls, respectively.

Correlations among number of SCD, PT bull EBV, sire EBV, and dam EBV are shown in Table 7. The PT bull EBV for ICO and FS had the highest correlation with SCD (0.41 and 0.36, respectively). Protein showed higher correlation with SCD than remaining production traits.

Correlations between dam FS and SCD and between dam ICO and SCD (0.25 and 0.18, respectively) were similar to correlations between sire FS and SCD and between sire ICO and $\operatorname{SCD}(0.22$ and 0.17 , respectively). In addition, dam UDC had a correlation of 0.16 with number of SCD. Correlation between number of SCD and dam EBV and between number of SCD and sire EBV for production traits were not statistically significant. Dams had slightly higher correlations than sires, despite the lower accuracy of female EBV. These results reflect the importance of using highly selected dams when selecting young bulls.

No PT bull was successful (had SCD) when its EBV (in SD units) was below $0.03,-0.06$, or 0.19 for milk, fat, and protein, respectively. Bulls had a less than $1 \%$ chance of success when their EBV (in SD units) were below 0.81 or 0.88 for FS and ICO, respectively, or had a negative EBV for FL or UDC. These values could be considered marketing thresholds.

Table 8 shows the success rate in accordance with genetic SD units of bull EBV for milk, fat, protein, FL, UDC, FS, and ICO. An EBV of FS of +2 SD units above mean led to higher probability of success (35\%) than +2 SD units for remaining traits and indices (23 to $29 \%$ ). When FS and protein were +2.5 SD units, probability of

Table 7. Pearson correlations among number of daughters in second crop (SCD), adjusted estimated breeding value (EBV ${ }^{\mathrm{a}}$ ) of the bulls, $\mathrm{EBV}^{\mathrm{a}}$ of the sire, and $\mathrm{EBV}^{\mathrm{a}}$ of the dam. Traits included milk, fat, protein, overall feet and legs index (FL), udder composite (UDC), final score (FS), and Spanish selection index (ICO). $\mathrm{N}$ is number of data.

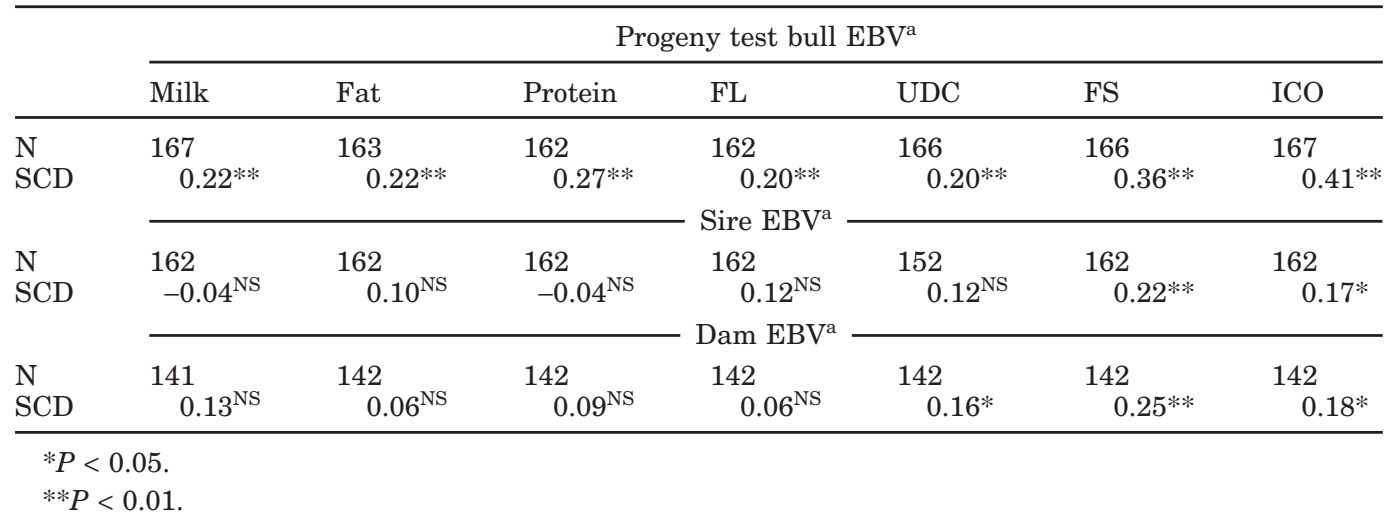


Table 8. Probability of success (likelihood of having second-crop daughters, \%) for progeny test bulls by units of standard deviation (SD) for EBV for milk, fat, protein, overall feet and legs index (FL), udder composite (UDC), final score (FS), and Spanish type-production selection index (ICO).

\begin{tabular}{llllllll}
\hline EBV SD units & Milk & Fat & Protein & FL & UDC & FS & ICO \\
\hline+1 & 17 & 19 & 18 & 22 & 20 & 23 & 15 \\
+1.5 & 17 & 21 & 19 & 22 & 20 & 31 & 17 \\
+2 & 24 & 23 & 29 & 23 & 26 & 35 & 26 \\
+2.5 & 27 & 31 & 62 & 23 & 33 & 55 & 39 \\
+3 & 33 & 33 & $\ldots$ & 40 & $\ldots$. & 60 & 73 \\
\hline
\end{tabular}

${ }^{1}$ No data were registered.

success for those bulls was over 55\%, and it was $39 \%$ for bulls with +2.5 SD units of ICO, and lower for remaining traits and indices. A higher probability of success was found as FS increased. The ICO was not as important for success until it was above $+2 \mathrm{SD}$ units. The PT bulls with ICO below +2 SD units were successful only when they had high protein or FS EBV. Protein and FS was determinant for success of PT bulls with lower ICO. Zhang et al. (1994) reported a probability of success of over $40 \%$ for PT bulls selected by 10 th percentile PI for Canadian Lifetime Profitability In$\operatorname{dex}(\mathrm{LPI})$.

\section{CONCLUSIONS}

Proven bulls from the Spanish PT program studied have been used significantly even though less than 32 young bulls were sampled per year. The genetic gain in Spain has been higher than in many other countries. Only the United Kingdom had higher genetic gain (sampling 80 to 130 bulls per year). Low test capacity is not synonymous with lower genetic gain when a high selection intensity is applied to parents of sampled bulls and the parents are taken from the worldwide population.

Breeding organizations should search for the best dams in the available population. Selecting heifers as dams for young bulls shortens the generation interval, but involves a certain risk because the EBV of such dams are known with much less certainty.

\section{ACKNOWLEDGMENTS}

The authors express their appreciation to Tom Lawlor and Juan Pena of the US and Spanish Holstein Associations, respectively, for providing the data on dams.

\section{REFERENCES}

Burnside, E. B., G. B. Jansen, G. Civati, and E. Dadati. 1992. Observed and theoretical genetic trends in a large dairy population under intensive selection. J. Dairy Sci. 75:2242-2253.

Butcher, K. R., and J. E. Legates. 1975. Estimating son's progeny test from his pedigree information. J. Dairy Sci. 59:137-152.

Dekkers, J. C. M., G. E. Vandervoort, and E. B. Burnside. 1996. Optimal size of progeny groups for progeny-testing programs by artificial insemination firms. J. Dairy Sci. 79:2056-2070.

Interbull. 2004a. International routine genetic evaluation on February 2004. Online. Available http://www-interbull.slu.se/eval/ framesida-genev.htm. Accessed Feb. 29, 2004.

Interbull. 2004b. National GES information. Online. Available http:// www-interbull.slu.se/national_ges_info2/framesida-ges.htm. Accessed Feb. 29, 2004.

Mao, I. L., M. C. Dong, and C. E. Meadows. 1991. Selection of bulls for progeny testing using pedigree indices and characteristics of potential bull-dams herds. J. Dairy Sci. 74:2747-2756.

Meinert, T. R., R. E. Pearson, and R. S. Hoyt. 1992. Estimates of genetic trend in an artificial insemination progeny test program and their association with herd characteristics. J. Dairy Sci. 75:2254-2264.

Nicholas, F. W., and C. Smith. 1983. Increased rates of genetic change in dairy cattle by embryo transfer and splitting. Anim. Prod. 36:341-353.

Norman, H. D., R. L. Powell, J. R. Wright, and C. G. Sattler. 2003. Timeliness and effectiveness of progeny testing through artificial insemination. J. Dairy Sci. 86:1513-1525.

Powell, R. L., H. D. Norman, and A. H. Sanders. 2003. Progeny testing and selection intensity for Holstein bulls in different countries. J. Dairy Sci. 86:3386-3393.

SAS Institute. 1998. User's Guide, Release 6.12. SAS Institute Inc., Cary, NC.

Weigel, D. J., R. E. Pearson, and I. Höeschele. 1994. Impact of different strategies and amounts of preferential treatment on various methods of bull-dam selection. J. Dairy Sci. 77:3163-3173.

Willam, A., C. Egger-Danner, J. Sölkner, and E. Gierzinger. 2002. Optimization of progeny testing schemes when functional traits play an important role in the total merit index. Livest. Prod. Sci. 77:217-225.

Zhang, W. C., L. R. Schaeffer, J. C. M. Dekkers, and H. DeBoer. 1994. Pedigree indexing of young Holstein bulls based on animal model evaluations. Proc. 5th World Congr. Genet. Appl. Livest. Prod. Vol. 17. Guelph, Ontario. Canada. 